\title{
LOS MITOS INDIGENAS \\ EN LA OBRA DE CARLOS FUENTES
}

\author{
POR \\ MALVA E. FILER \\ Brooklyn College, City University of New York
}

El movimiento indigenista mexicano, al igual que el que se manifiesta en la zona andina, tiene conciencia, desde sus orígenes, de estar impulsado por una ideología no representativa del indio, sino del mestizo ${ }^{1}$. Como bien aclara Gonzalo Aguirre Beltrán ${ }^{2}$, indigenismo y mestizaje son procesos complementarios. El indigenismo requiere «el substratum humano que le suministra el mestizaje», y «éste a su vez requiere, para dar contenido y significación a la vida, el sistema axiológico», que sólo el indigenismo puede proporcionarle. Se trata, pues, de un proceso en el cual «la interdependencia entre la base orgánica y la expresión cultural deviene indispensable». El indigenismo, como ideología del mestizo, y el mestizaje mismo, como proceso vivo, son las dos caras de un movimiento de unificación nacional que surge del choque entre fuerzas de signo opuesto: el indianismo y el occidentalismo. El indianismo dio impulso en México a la idealización romántica del pasado azteca, pero fue ineficaz instrumento para cambiar la estructura de una sociedad explotadora del indio y del mestizo. El occidentalismo - tanto en su vertiente conservadora, y en algún grado racista, que propugna la imposición de modelos europeos o estadounidenses, como en su vertiente marxista, que equipara la situación del indio a la de todos los campesinos explotados - no valora

\footnotetext{
${ }^{1}$ José Carlos Mariátegui afirma, en Siete ensayos de interpretación de la realidad peruana (Lima: Biblioteca «Amauta», 1975), que la literatura indigenista «es todavía una literatura de mestizos. Por eso se llama indigenista y no indígena» (p. 335). Véanse al respecto los comentarios de Antonio Cornejo Polar en «El indigenismo y las literaturas heterogéneas: su doble estatuto sociocultural», Revista de crítica literaria latinoamericana, año IV, núms. $7-8$ (Lima: Latinoamericana Editores, 1978), pp. 7-21.

${ }^{2}$ Gonzalo Aguirre Beltrán, El proceso de aculturación (México: UNAM, 1957), p. 127.
} 
ni reconoce la tradición y la cultura de los pueblos indígenas. Los indigenistas mexicanos, entre los que destacan Manuel Gamio, Moisés Sáenz, Alfonso Caso y el ya citado Aguirre Beltrán, rechazan las dos posiciones mencionadas. Según este último, «el proceso de aculturación, por medio del cual dos culturas en contacto intercambian elementos y los reinterpretan para dar eventual nacimiento a una nueva cultura, distinta de las originalmente concurrentes, constituye el fenómeno subyacente a la posición indigenista» (El proceso de aculturación, p. 140). Lo que ésta propugna, pues, es el afianzamiento y consolidación de la cultura resultante de dicho proceso, esto es, la cultura mestiza. El indigenismo en México, del mismo modo que el de los otros países en que ha evolucionado, es más que un movimiento reivindicatorio de carácter político-social, ya que también se propone la incorporación de las culturas marginadas al proceso formativo de una verdadera identidad nacional. A este objetivo converge un imponente caudal de pensamiento, investigación científica y creación artística que ha contado con las grandes figuras de José Vasconcelos, Alfonso Caso, Leopoldo Zea, Octavio Paz, Manuel Gamio, Fernando Benítez y muchos otros distinguidos etnógrafos, arqueólogos, artistas plásticos y escritores. Las obras de Juan Rulfo, Rosario Castellanos y Carlos Fuentes representan, diversamente, la herencia de esta indagación en lo mexicano, tal como se manifiesta desde mediados de siglo.

La trayectoria de Carlos Fuentes a lo largo de tres décadas de producción literaria revela, como una de sus constantes, la convicción de que México debe integrar sus componentes indígenas y europeos, sus raíces históricas y su modernidad, y elaborar con lo mejor y más perdurable de ellos su propia y auténtica cultura. La expresión más clara de estos conceptos se encuentra en los ensayos de Tiempo mexicano, donde México es descrito como un país en el que coexisten, conflictivamente, diversas tradiciones históricas: las concepciones míticas y cósmicas indígenas, la versión española del cristianismo, los valores individualistas de la burguesía europea y la fe en la ciencia, la razón y el progreso de los países industrializados. "Optar actualmente por una sola de estas líneas históricas es —según Fuentes - imposible o indeseable; en cambio, es posible y deseable intentar una fusión de sus respectivos valores, pero sólo con el propósito de ir, una vez alcanzada la síntesis, más allá de ella» ${ }^{3}$. Los ensayos de Tiempo mexicano representan, por tanto, una reformulación hecha por Fuentes de los mismos principios que orientan al indigenismo, según la interpretación arriba expuesta de este movimiento. En su obra de ficción surgen, como veremos, las fuerzas conflictivas, aún no integra-

${ }^{3}$ Carlos Fuentes, Tiempo mexicano (México: Joaquín Mortiz, 1972), p. 39. 
das, que han de incorporarse a la nueva síntesis. Nuestro estudio se propone destacar, particularmente, el papel asignado a los mitos indígenas en su búsqueda de conceptos y de imágenes expresivos de la mexicanidad.

Luis Leal señala el hecho de que la obra de Fuentes presenta, desde sus primeros cuentos de Los días enmascarados hasta su reciente novela Una familia lejana, distintos grados de fusión de la historia y el mito. Esta fusión le ha permitido «no sólo revelar importantes aspectos de la mente y el carácter del pueblo mexicano, sino también proyectar sus propias esperanzas y aspiraciones», una de las cuales es el asegurar la supervivencia del pasado ${ }^{4}$. El cuento «Chac-Mool», por ejemplo, se relaciona con un hecho ocurrido en 1952: una exhibición mexicana en Europa, que incluía al dios maya de la lluvia, y cuya mera presencia había causado lluvias, según las noticias periodísticas leídas por Fuentes ${ }^{5}$. Con tal material elabora el autor su cuento, en el que reconocemos la expresión temprana de uno de sus temas recurrentes: la interacción entre un pasado indígena que se rehúsa a morir y un México moderno que tiende a desconocer sus propias raíces. Según el relato, Felisberto, un empleado público atraído por el arte indígena, compra una réplica de piedra del ChacMool, y la agrega a la colección de estatuillas, ídolos y cacharros que guarda en el sótano de su casa. El dios de la lluvia cobra vida y perturba para siempre la existencia burocrática del personaje, el cual pierde su empleo y, desesperado, se escapa a Acapulco, donde muere misteriosamente ahogado. Chac-Mool se encarna en un viejo indio, quien recibe al amigo de Felisberto al llegar aquél a casa de éste trayendo el féretro con su cadáver. El pasado indígena aparece aquí como una fuerza ancestral vengativa y destructora. En otro de sus primeros cuentos, «Por boca de los dioses» ${ }^{6}$, el encuentro entre el pasado indígena y el México moderno se produce en la habitación del protagonista, la cual tiene el simbólico número 1519, fecha del arribo de Cortés a México. La supervivencia del pasado pre-hispánico está representada, nuevamente, como una fuerza destructiva a través de la figura de Tlazol, nombre abreviado de Tlazoltéotl, la «Diosa de la inmundicia». Ella prevalece sobre otros dioses mayores y menores del panteón azteca, algunos benévolos y otros malignos, que el protagonista enfrenta en un misterioso subterráneo. Pero el texto de «Chac-Mool» también sugiere una forma positiva de supervivencia que es producto de un proceso de integración religiosa y cultural. Pepe,

${ }^{4}$ Luis Leal, «History and Myth in the Narrative of Carlos Fuentes», Carlos Fuentes. A critical View. Ed. by R. Brody and Ch. Rossman (Austin: Univ. of Texas Press, 1982), pp. 15-16.

${ }^{5}$ Carlos Fuentes, nota 5, p. 16.

${ }^{6}$ Carlos Fuentes, Los días enmascarados (México: Los Presentes, 1954). 
el amigo de Felisberto, atribuye la facilidad con que los indios abrazaron el cristianismo a que encontraron en éste «un sentido cálido, sangriento, de sacrificio y liturgia», en el que vieron «una prolongación natural y novedosa de la religión indígena» ${ }^{7}$. El indio aceptó del cristianismo lo que le era afín, y, para poder adoptarlo, tuvo que encuadrarlo dentro de las pautas de su propia cosmovisión. El sincretismo religioso y sus manifestaciones artísticas son un aspecto del mestizaje que Fuentes describe con particular viveza en sus novelas. En La muerte de Artemio Cruz leemos, por ejemplo:

Y tú atravesarás bajo el sol la ancha explanada con la cruz de piedra en el centro y las capillas abiertas, la prolongación del culto indígena, teatral, al aire libre, en los ángulos... Avanzarás y penetrarás en la nave del bajel, donde el exterior castellano habrá sido vencido por la plenitud, macabra, sonriente, de este cielo indio de santos, ángeles y dioses indios. ... Santos de un cielo inventado por el indio a su imagen y semejanza: ángeles y santos con el rostro del sol y la luna, con la mano protectora de las cosechas, con el dedo índice de los canes guiadores, con los ojos crueles, innecesarios, ajenos, del ídolo, con el semblante riguroso de los $\operatorname{ciclos}^{8}$.

Y en Cambio de piel se describe la iglesia de Cholula, cuyo Cristo tenía las cinco heridas «estilizadas a la manera indígena: la mayor coronada de plumas y las gotas de sangre, siempre, como un puñado de moras silvestres». Las enormes pilas bautismales «no eran sino urnas de piedra indígenas, viejas, labradas, corroídas, antiguos depósitos de los corazones humanos arrancados por el pedernal en los sacrificios de Cholula» ${ }^{9}$. La propia figura de Cristo y el significado de su sacrificio son interpretados por los indígenas de modo afín a sus antiguas creencias. En Tiempo mexicano Fuentes se refiere al hecho, observado por Fernando Benítez, de que para los indios coras Cristo no es una figura mesiánica, sino un dios fundador, instalado en los orígenes. «Su sacrificio no redime a la humanidad pecadora, pero asegura nuevamente que, gracias a la sangre derramada, crecerá sobre la tierra el maíz de Quetzalcóatl, el sol no se extinguirá, las lluvias serán puntuales» (p. 25).

La idea de la necesidad del sacrificio humano, proveniente de la mitología azteca, es, según Fuentes, una fuerza aún vigente en el México moderno. El cree que «el sentido permanente del sacrificio», concebido como requisito para mantener el orden del cosmos, ha sido «la victoria final del

${ }^{7}$ Carlos Fuentes, Chac-Mool y otros cuentos (Navarra: Salvat, 1973), p. 19.

${ }^{8}$ Carlos Fuentes, La muerte de Artemio Cruz (México: FCE, 1967), pp. 35-36.

${ }^{9}$ Carlos Fuentes, Cambio de piel (México: Joaquín Mortiz, 1967), pp. 18-19. 
mundo indígena en México» ${ }^{10}$. Esta afirmación, hecha con anterioridad a los sucesos trágicos de Tlatelolco, ocurridos el 2 de octubre de 1968, concuerda con los juicios emitidos por Octavio Paz en «Crítica de la pirámide», escrita con posterioridad y como reacción a dichos acontecimientos. Dice allí Paz que "para los herederos del poder azteca, la conexión entre los ritos religiosos y los actos políticos de dominación desaparece, pero... el modelo inconsciente del poder siguió siendo el mismo: la pirámide y el sacrificio» ${ }^{11}$. Paz sólo se refiere, sin embargo, a los aztecas, en los que ve representados principios opuestos a los de las civilizaciones clásicas que ellos dominaron ${ }^{12}$. El tema del sacrificio aparece por primera vez, en Fuentes, en La región más transparente ${ }^{13}$, a través de las figuras simbólicas de Teódula Moctezuma e Ixca Cienfuegos. Ixca hace referencia al mito de la creación del sol y al sacrificio del dios leproso que «se arrojó al brasero de la creación original para alimentarlo», y «renació convertido en astro». Afirma, como los antiguos aztecas, que «era preciso un sacrificio diario, un alimento diario para que el sol iluminara, corriera y alimentara a su vez» (254). Teódula tiene características que la identifican con la diosa madre en la representación de Coatlicue (Falda de serpientes), también conocida como la madre de Huitzilopotchtli ${ }^{14}$. Esto se hace evidente en la descripción de Teódula frente a la casa incendiada en que muere Norma, arrancándose las joyas para arrojarlas al fuego (395-396). Fuentes mismo ha confirmado la identificación de su personaje con la diosa azteca de la creación y la destrucción, a la que llama «Tonantzin», nombre popular que significa «nuestra madre» ${ }^{15}$. La muerte de Norma es celebrada por Teódula como un sacrificio expiatorio, un sacrificio que ha de servir para restablecer el orden antiguo. Ella simboliza el rechazo de la modernidad, y la creencia de que es necesario, y posible, volver a acatar las normas del pasado. Gloria Durán señala que

${ }^{10}$ Emir Rodríguez Monegal, «Carlos Fuentes», Homenaje a Carlos Fuentes, edición a cargo de H. F. Giacomán (New York: Las Américas, 1971), p. 31.

$"$ Octavio Paz, «Crítica de la pirámide», Posdata (México: Siglo XXII, 1970), pp. 113-114.

${ }_{12} \mathrm{Cf}$. Octavio $\mathrm{Paz}$, El punto de vista nahua», Puertas al campo (Barcelona: Seix Barral, 1972).

${ }^{13}$ Carlos Fuentes, La región más transparente (México: FCE, 1968).

${ }^{14}$ Cf. María A. Salgado, «El mito azteca en La región más transparente», Homenaje, nota 5, p. 237.

${ }_{15}$ Cf. Carta de Carlos Fuentes a Gloria Durán, fechada en París, 8 de diciembre de 1968, reproducida por ella en el «Apéndice» a La magia y las brujas en la obra de Carlos Fuentes (México: UNAM, 1976). Véase también la descripción de Coatli. cue, hecha por Alfonso Caso, en La religión de los aztecas (México: Secretaría de Educación Pública, Biblioteca Enciclopédica Popular, núm. 38, 1945), p. 45. 
Teódula, identificada como «Tonantzin», madre de los dioses y de los hombres, no puede ser, como tal, «madre de sangre» para Ixca, y afirma que la obediencia de éste a Teódula no es la del hijo, sino la del creyente ${ }^{16}$. Ixca también siente, como Teódula, que está aún vivo el México de Huitzilopochtli y sus ritos sangrientos, a los que obviamente alude al comienzo del texto. Pero él ya vive la superposición del orden viejo y el presente, que se le aparecen como «dos imágenes dinámicas» que «se disolvían la una en la otra, cada una espejo sin fondo de la anterior o de la nueva» (242). El quisiera «recoger los fragmentos rotos del origen y volver a tocarlos íntegros» (243). Al final de la novela se identifica, sin embargo, con el proceso viviente, transformador de tradiciones diversas del México «de los tres ombligos» (457), y no con el «sol detenido» (ibíd.) que representa Teódula.

La defensa del México mestizo está formulada, con mayor lucidez, en los argumentos del intelectual Zamacona. Este cree fútil el cuestionamiento obsesivo del origen que preocupa a Ixca y afirma que «lo original es lo impuro, lo mixto. Como nosotros, como yo, como México. Es decir, lo original supone una mezcla, una creación, no una puridad anterior a nuestra experiencia. Más que nacer originales, llegamos a ser originales: el origen es una creación. México debe alcanzar su originalidad viendo hacia adelante; no la encontrará atrás» (58). En vez de buscarse en un pasado azteca, que «sólo nos explica parcialmente», y que es imposible resucitar, hay que explicar el México que «ya es otra cosa» y proyectarse hacia un futuro en el que todos sus componentes hayan sido integrados. En La región más transparente están explícitos, pues, el rechazo del indianismo, con su nostalgia idealizadora del pasado, y la afirmación de una postura indigenista, para la cual México se identifica con el dinamismo creador del mestizaje, tanto biológico como cultural.

En las novelas posteriores a La región más transparente, Fuentes continúa interpretando una cosmovisión basada en la necesidad del sacrificio, pero éste ya no es concebido como requisito para el restablecimiento del viejo orden, sino como vehículo de transformación, dentro de una visión cíclica del universo. La muerte de Artemio Cruz presenta, tanto en el plano individual como en el colectivo, el final de un ciclo, el de los caudillos que ascendieron con la Revolución y se transformaron en la nueva clase detentadora del poder político y económico. René Jara C. señala que Artemio "participa del ritmo cíclico del universo», acorde con la concepción azteca del tiempo. Ve prueba de ello en el carácter ritual de la fiesta de Coyoacán, que marca en la novela, según deduce Jara, los cin-

${ }^{16}$ La magia y las brujas..., p. 77. 
cuenta y dos años de vida pública del caudillo. Esta observación se ve corroborada por la importancia que da Fuentes a este aspecto de la concepción azteca del tiempo en Tiempo mexicano y en Cambio de piel: «Cada cincuenta y dos años, al cumplirse el ciclo más vasto, lo anterior debe ser cancelado, negado, destruido o recubierto como las siete sucesivas pirámides del centro ceremonial de Cholula» (Tiempo mexicano, p. 27). La descripción de la fiesta de Coyoacán sugiere, en efecto, que el ciclo de Artemio Cruz se ha cerrado y que los participantes están cumpliendo, consciente o inconscientemente, con un rito de pasaje: «Estalló la gritería del nuevo año... esta pira de la memoria, esta resurrección fermentada... de todos los hechos, palabras y cosas muertas del ciclo» (259). La concepción cíclica está implícita, por otra parte, en toda la novela: el nacimiento de Artemio, hijo bastardo del hacendado Menchaca y una sirvienta mulata, coincide con el asesinato del padre y con la caída de los Menchaca y de su clase surgida al amparo del general Santa Anna. Su propio ascenso político significa el descenso de Bernal y de los que, como éste, habían prosperado bajo el porfiriato. La fiesta de Coyoacán anticipa, además, la inminente transmisión del poder a la generación representada por Jaime Ceballos (cf. pp. 266-269).

Al volver sobre el tema del cambio cíclico, en Cambio de piel Fuentes trasciende la interpretación político-social de la historia para remontarse a una visión mítica del cambio como un proceso de muerte y renacimiento. En La región más transparente había referencia, como ya mencionamos, al sacrificio originario del dios leproso que se arrojó a la hoguera de donde surgió transformado en astro. Pero éste era un sol inmóvil, y para que tuviera vida y movimiento debieron sacrificarse otros dioses. Así como ellos ofrendaron su vida para que viviera el planeta, los hombres debían sacrificarse periódicamente, para asegurar con su sangre la continuidad de la vida. La destrucción periódica de lo viejo era, también, necesaria para que se renovara la existencia. Cambio de piel ofrece una visión de la historia regida por el tiempo cíclico que representan las siete pirámides de Cholula (cf. p. 292). Xipe Totec, «nuestro señor el desollado», con quien se identifica el narrador, era —según explica Jacques Soustelle - un «dios corporativo de los orfebres y también divinidad de la lluvia primaveral, de la renovación de la naturaleza y de las plantas» ${ }^{17}$. Fuentes vuelve a mencionarlo en Terra Nostra y en Una familia lejana, y en ambas novelas evoca el sacrificio de este dios, quien da su vida por la siguiente cosecha y, para escapar de sí mismo, se desprende

${ }^{17}$ Jacques Soustelle, La vida cotidiana de los aztecas (México: FCE, 1956), p. 111 . 
de su piel ${ }^{18}$. En Cambio de piel, las mutaciones y los trastornos surridos por la humanidad a través de su historia quedan inscritos en este drama universal de muerte y renacimiento simbolizado por la figura de Xipe Totec. Confrontando siglos de violencia, de injusticia y de utopías desenmascaradas, Fuentes reafirma mediante el mito la existencia de fuerzas regenerativas en las que sigue viviente un germen transformador. Sin embargo, su novela es pesimista y niega, como el autor también lo ha hecho, la idea del progreso histórico (cf. p. 424) ${ }^{19}$. Mediante el personaje de Javier el texto ilustra además el incumplimiento del proceso integrador propugnado por el indigenismo. Vemos, en efecto, la contradicción que existe entre su actitud crítica frente al México moderno, desconectado de su pasado indígena, y su reacción espontánea, visceral, frente a las masas incultas de mestizos, que son el residuo viviente de ese pasado. La distancia, el rechazo y el temor que experimenta hacia estos mexicanos desposeídos le hacen exclamar: "No hablamos como ellos. No pensamos como ellos. Nunca nos hemos detenido a mirarlos. Les damos órdenes. Si venimos a verlos es como ir al zoológico... Somos enemigos» (114). Javier siente como amenazadora la presencia de «estos millones de seres oscuros, con su pasividad intolerable, con su violencia atroz, con sus sonrisas sin alegría, con su tristeza a carcajadas, brutal, rencorosa» (201). Sus lucubraciones intelectuales no ofrecen nada a esta masa de pueblo marcada por «siglos de humillación y de venganzas frustradas». Dentro de la economía de la novela, Javier es la representación de lo ya intentado y de su fracaso. Fuentes apunta, a través de este personaje, a una realidad diferente que ha de reemplazar la realidad ya exhausta que él representa. $\mathrm{La}$ inauguración de un nuevo ciclo, anticipado por toda la novela, queda, sin embargo, fuera de ella. No ha encarnado aún en ficción.

La imagen del «cambio de piel» continúa atrayendo al autor, como puede observarse en Zona sagrada y en Una familia lejana. En la primera, el personaje de Claudia es equiparado, en efecto, con Tlazoltéotl, «la diosa indígena de la muerte, la fertilidad y la inmundicia» ${ }^{20}$. Para Guillermo (Mito), ella es la proveedora que nutre y sostiene, pero también la percibe como un poder destructor. No puede "distinguirla de sus riquezas y sabidurías prácticas, de sus frutos, de sus alimentos, de la mis-

${ }^{18}$ Carlos Fuentes, Terra Nostra (México: Joaquín Mortiz, 1975), p. 477; Una familia lejana (México: Era, 1980), p. 176.

${ }^{19}$ Homenaje, p. 41. La relación entre el pesimismo en la ficción de Fuentes y su visión, mucho más positiva, de Tiempo mexicano ha sido estudiada por mí en «A Change of Skin and the Shaping of a Mexican Time», en Carlos Fuentes, pp. 121-131.

${ }^{20}$ Carlos Fuentes, Zona sagrada (México: Siglo XXI, 1967), p. 45. 
ma manera que la tierra no se distingue de los árboles que le crecen o de los ríos que la recorren» (44). Pero teme que ella lo destruya, como Tlazoltéotl destruye periódicamente la vegetación después de cada cosecha ${ }^{21}$. Mito piensa, escuchando a su madre: «Qué problema, levantar las cosechas de la tierra cuando se cree que equivale a mutilarla, a raparla: rapto y rapiña, buitres... Pero el zopilote también purifica, es el que rapta lo innecesario, la basura y los cadáveres» (45). Tlazoltéotl era también llamada tlaelquani, "devoradora de inmundicias», es decir, la que devora los pecados ${ }^{22}$. El texto identifica a Claudia con esta antigua diosa de la regeneración y la presenta también como símbolo del México moderno, con su cosmopolitismo, sus astutas especulaciones financieras y su actitud ambivalente hacia los Estados Unidos. Guillermo no participa del poder transformador de su madre ni tampoco se ha esforzado por comprenderla. Ha preferido el derrotismo, el sufrimiento fácil y estéril, como él mismo confiesa: "Y yo me he negado a conocerla. Yo me he negado a indagar el misterio de una lucha dolorosa y solitaria... Debo admitir que acercarme a ella verdaderamente hubiera significado perder mi fatalidad querida y el tono indulgente de compasión hacia mí mismo que la acompaña» (179). En estas reflexiones puede leerse una crítica de Fuentes, dirigida a aquellos de sus connacionales que frecuentemente declaran su admiración y su sentimiento de pérdida por la desaparecida cultura prehispánica, pero que no buscan comprender y revitalizar los elementos de la misma que aún subyacen, latentes, en la intrahistoria mexicana.

En obras posteriores, particularmente en Terra Nostra, la preocupación por recuperar el pasado, y específicamente el pasado, que es substrato de la mexicanidad, encarna en textos no sólo recreadores, sino «fundadores ${ }^{23}$. Esto concuerda con ideas expresadas por el autor en una reciente entrevista: «Beyond the knowledge of science, of logic and politics, there is the knowledge we call imagination. And it is only achieved through a verbal structure we call a poem or a novel. This is an important thing to keep alive in order to compensate for many of the voids of history ${ }^{24}$. Este conocimiento imaginativo, que se nutre de mitos, tiene en Fuentes una función regenerativa e integradora de la historia. Prueba de ello es la

${ }^{21}$ Cf. Philip Koldewyn, "Meditation and Regeneration in the Sacred Zones of Fiction: Carlos Fuentes and the Nature of Myth», Journal of Latin American Lore, Volume 7, Number 2, Winter 1981, p. 159.

${ }^{22}$ Soustelle, p. 110.

${ }^{23}$ Uso este término en el sentido que le ha dado Octavio Paz en «Literatura de fundación», Puertas al campo, pp. 15-21.

${ }^{24}$ "The Many Worlds of Carlos Fuentes», Bill Moyers' Journal (Transcript of PBS program aired June 19, 1980), p. 4. 
segunda parte de Terra Nostra, «Mundo nuevo», texto que puebla un vacío, que reconstruye un mundo perdido. Lotman y Uspensky señalan que, para que haya cultura, debe haber una memoria no hereditaria de la comunidad, y esto presupone la existencia de un sistema mediante el cual se registre, y se traduzca en texto, la experiencia directa. La destrucción de sus textos produce la desintegración de una cultura como personalidad colectiva unificada, esto es, poseedora de una continua autoconciencia y de experiencia acumulada ${ }^{25}$. Frente a los textos destruidos de la cultura indígena, Fuentes erige la estructura verbal de su texto. E1 mundo azteca, y sus figuras legendarias, son reinstaurados en la historia, son incluidos en el drama de la condición humana universal.

El narrador de «mundo nuevo» es reconocido como Quetzalcóatl, el dios benéfico, opuesto a los sacrificios humanos; él es un Prometeo mexicano que bajó al mundo de los muertos para recoger los huesos de las generaciones pasadas $\mathrm{y}$, regándolas con su propia sangre, creó la nueva humanidad. A pesar de sí mismo, sin embargo, Quetzalcóatl hace surgir a su contrario, Tezcatlipoca, el dios nocturno, patrono de hechiceros y malvados, cuyo nombre significa «el espejo que humea». Tezcatlipoca está caracterizado en los códices por un espejo humeante que lleva en la sien y por otro que sustituye al pie que le arrancó el monstruo de la tierra (cf. Alfonso Caso, La religión de los aztecas). El narrador, en quien luchan las fuerzas del bien y del mal, la Serpiente de Plumas y el Espejo Humeante, es también el europeo blanco, civilizador cristiano y cruel conquistador. Quetzalcóatl, el mensajero de la paz y la bondad, es vencido y anulado por un demonio que es su "otro», que es parte de su propia identidad. En el espejo de éste, el narrador confronta su lado oscuro, los veinte días, o siglos, que ha olvidado y que «fatalmente ocurrirán en el futuro» (480). Se ve a sí mismo «blanco, rubio, barbado, a caballo, ... con una cruz de oro bordada al pecho», matando, destruyendo, esclavizando, ejerciendo actos de máxima crueldad y enriqueciéndose con los despojos de un mundo en ruinas (477-478). El narrador mata a su "otro», pero el "gemelo oscuro» renacerá en él y seguirá combatiéndolo. El mundo y su historia son el escenario de esta lucha sin fin; el bien sólo se mantiene vivo porque el mal —que es su «otro»- lo niega. La lucha permanente entre Quetzalcóatl y Tezcatlipoca es necesaria, ya que ella promueve el cambio cíclico que es instrumento de la transformación universal ${ }^{26}$. Es evidente que Fuentes sigue de cerca el texto de la leyenda

${ }^{25}$ Yu. M. Lotman and B. A. Uspensky, «On the Semiotic Mechanism of Culture», New Literary History, Volume IX, Number 2, Winter 1978, pp. 214-216.

${ }_{26}$ Cf. José López Portillo, Quetzalcóatl (Barcelona: Salvat, 1976), p. 171. 
que enfrenta a las dos figuras míticas, único documento salvado de la destrucción de Tula, el centro de la cultura «tolteca», cuando ésta cayó bajo la dominación azteca. El texto de Terra Nostra incluye mención, sin embargo, de un hecho que remite a la realidad histórica oculta tras la oposición mítica: la quema de los códices, con la cual se inició, según Paz explica, una «rectificación de la historia. La desfiguración y enmienda de las tradiciones, los mitos y la teología tuvieron el doble propósito de borrar los orígenes rústicos del pueblo mexica y de sus dioses y, así, legitimar su pretensión de ser los herederos de los toltecas» ${ }^{27}$. En la novela, Espejo Humeante quema la leyenda de Quetzalcóatl (462) para establecer la legitimidad de su poder: «Hoy quemé los papeles de tu leyenda. Ya no hay nada escrito sobre ti. Por allí empezaré, hasta convertir la memoria de ti en cenizas como las que hoy barrí con la escoba» (477). Pero ni la derrota ni el triunfo son definitivos para Quetzalcóatl. Según las sabias palabras del «anciano de las memorias», pronunciadas frente a una plaza de Tlatelolco de todos los tiempos ${ }^{28}$, su destino es ser perseguido. «Luchar. Ser derrotado. Renacer de tu derrota. Regresar. Hablar. Recordarle lo olvidado a todos. Reinar por un instante. Ser derrotado de nuevo por las fuerzas del mundo. Huir. Regresar. Recordar. Un trabajo sin fin» (483). La visión dualista del texto se completa, además, con la identificación final del «nuevo mundo», en su totalidad, como doble del Viejo (494) ${ }^{29}$.

La dualidad masculina de Quetzalcóatl-Tezcatlipoca tiene su contraparte femenina en Terra Nostra, en la figura de la diosa madre, Tonantzin, cuya presencia ya habíamos señalado en las obras anteriores del autor. Aunque no se la nombra, ella aparece en el texto con su doble función de creadora y destructora, en caracterizaciones que coinciden con las que se dan de Coatlicue ( la falda de serpientes») y Tlazoltéotl («Diosa de la inmundicia»). Se la describe como una «aparación de deslumbrante belleza y deslumbrante horror» (412). La joven diosa del amor, «señora de las mariposas», es también la diosa cruel, de cabellera em-

${ }^{27}$ Puertas al campo, pp. 139-140.

${ }_{28}$ Tlatelolco, la Plaza de las Tres Culturas, donde ocurrió la masacre de 1968, había sido escenario de otra masacre, perpetrada cuatrocientos cincuenta años antes por Pedro de Alvarado. Estos hechos históricos son testimonio de la continuidad de la violencia y la opresión, que el autor ve como hilo conductor a través de la historia.

${ }^{29}$ El texto sigue de cerca la traducción esotérica de Quetzalcóatl como «gemelo precioso", versión que indica, según explica Caso (La religión de los aztecas, p. 26), que «la estrella matutina y la vespertina son una sola y misma estrella, es decir, el planeta Venus, representado en la mañana por Quetzalcóatl y en la tarde por su hermano gemelo Xolote». 
barrada con la sangre de los sacrificios (432). Ella limpia los pecados y devora la inmundicia para purificar el mundo. Ante esta diosa pueden confesarse los penitentes una sola vez en su vida. La novela hace referencia al rito de la confesión, que se practicaba ante los sacerdotes de Tlazoltéotl (435). Y ella es, finalmente, «la bruja, la anciana destructora de los jóvenes» (471). El narrador pierde el acceso a la joven diosa, sus tiempos ya no coinciden. El cuerpo de la mujer, en su aparición tardía, sólo le ofrece «piedra, un pedernal, una roca impenetrable» (472). Ella le da, sin embargo, «el verdadero mapa de la tierra nueva... No el que conduce a los lugares visibles», sino el que lo conducirá un día de regreso a ella, «a lo invisible» (471). El regreso a lo invisible es también el camino emprendido imaginativamente por el autor en esta peregrinación de su personaje. Son, pues, significativas las palabras de éste luego de presenciar, horrorizado, los sangrientos ritos que ha relatado: «Mas yo quisiera que os pusierais en mi lugar aquel lejano día del espejo humeante y, a pesar del horror, compartierais mi hondo deseo de comprender lo que veía, y de darle al anhelo de comprensión poderes más vastos que el instinto de condenación» (437). Esta fascinante y terrible imagen del pasado de Terra Nostra es la respuesta del autor al expresado anhelo de autoconocimiento y de autoaceptación que recorre toda su obra. Fuentes cree, como Paz, que «la crítica de México y de su historia -una crítica que se asemeja a la terapéutica de los psicoanalistas - debe iniciarse por un examen de lo que significó y significa todavía la visión azteca del mundo» ${ }^{30}$. Su imaginación, que busca ser conocimiento, corresponde también a lo que Paz describe como una imaginación crítica. Al universalizar el dualismo de la teogonía indígena, Fuentes le restituye su sentido profundo y muestra, al mismo tiempo, que la historia de la Europa cristiana está signada por un maniqueísmo equivalente, aunque no reconocido y sancionado como el de los aztecas. Esta visión es, asimismo, la de Todos los gatos son pardos, reconstrucción dramática del enfrentamiento entre el poder de la fatalidad en Moctezuma y el poder de la voluntad en Hernán Cortés ${ }^{31}$.

Los temas expuestos reaparecen en Una familia lejana, donde vuelve a plantearse la relación entre Viejo y Nuevo Mundo y entre el mexicano moderno y su pasado indígena. Sus personajes, de apellido Heredia, representan, como veremos, opciones opuestas, pero igualmente negadoras

${ }^{30}$ Posdata, p. 127.

${ }^{31}$ El autor ha calificado esta obra como «una memoria personal e histórica», como un ritual que persigue «la desintegración de una vieja personalidad y su reintegración en un nuevo ser" (Carlos Fuentes, Los reinos originarios, Barcelona: Barral, 1971, pp. 17-20). 
de la identidad mexicana. El arqueólogo Hugo Heredia busca el sentido de su vida en las piedras, que le hablan de una civilización indígena destruida por sus antepasados. Heredero de privilegios conquistados a sangre y fuego por «patriarcas, jueces y carceleros», que cree desprovistos de grandeza, busca, paradójicamente, el fundamento de su identidad y la grandeza perdida en los monumentos que quedan de sus «víctimas». Este personaje, en el que vemos cierto parentesco con el Javier de Cambio de piel, exhibe un indianismo conservador y aristocratizante, acompañado de sentimientos despectivos hacia las masas de indios y mestizos sobrevivientes de siglos de explotación y miseria. Tanto él como su hijo Víctor experimentan sentimientos de insuficiencia, que intentan superar, pero por caminos opuestos. Hugo Heredia quiere, como arqueólogo, resucitar las voces del México indígena; suplir, como él dice, la «amnesia de nosotros mismos», «el olvido de lo que fuimos». Víctor busca completarse, en cambio, mediante la unión simbólica con lo que percibe como su mitad europea. A esta unión se llega, por misterioso designio, en una casa de Enghien-les-Bains. La cópula del mexicano de tez morena, pelo negro y lacio y ojos claros, con el francés blanco, de cabellera rubia y rizada, es presentada por la novela como otra versión del sacrificio ejemplar de Xipe Totec. Hugo sacrifica a su hijo porque éste no comparte su veneración por el pasado y no lo considera digno de ser su heredero. Con esta ofrenda consigue, en primer término, la reconstitución de una pieza arqueológica que Víctor había partido en dos mitades, en un acceso de furia. Para Hugo, ella era «un objeto emblemático de esa presencia del pasado», que era "la única razón profunda» de su vida (186). El sacrificio del hijo le es propuesto, además, como un rito de pasaje y como un requisito para que se recupere la memoria de los muertos. Tanto a nivel colectivo como personal, el arqueólogo afirma que el presente debe estar al servicio del pasado, o, en las palabras que atribuye al Heredia «francés», «los vivos deben servir a los muertos» (181). Estas y otras aseveraciones insólitas que emparentan a los dos Heredias con la Teódula de La región más transparente sólo cobran sentido si se interpretan desde el punto de vista azteca. El sacrificio, el de los dioses en los orígenes y el de los hombres luego, es una transmutación por la cual de la muerte surge la vida. La alusión a Xipe Totec por parte de Hugo indica que el sacrificio de Víctor es necesario para que su sangre renazca en un nuevo ser.

Una transmutación es precisamente lo que persigue el «otro Heredia», el señor del Clos des Renards, mediante la simbiosis del mexicano y el europeo. No se conforma, como el arqueólogo, con revitalizar el pasado, sino que quiere crear un pasado que debía haber sido. Busca la encarnación de un ser que nunca fue, un ser «completo», "otra vez entero», 
europeo y americano. En este nuevo hombre, tal vez un adelantado de la «raza cósmica» que profetizara Vasconcelos, volverán a unirse los dos fragmentos de la cultura de Occidente. La América mestiza ha sido para Europa lo otro, lo desconocido, lo no asimilable. El Nuevo Mundo fue - dice Fuentes - la última oportunidad de un universalismo europeo, pero también su tumba (121). El Heredia «francés» no acepta, sin embargo, este veredicto y anuncia, en cambio, la gestación del nuevo hombre. Víctor y André deben desaparecer como tales para que con ellos se forme una nueva identidad. La cópula homosexual connota, sin embargo, la idea de la esterilidad, y es difícil asociarla con la imagen de la producción de un ser nuevo. La descripción sugiere, por otra parte, el siguiente interrogante: ¿Qué quedará del joven mexicano una vez que se haya unido para siempre con su otra mitad? Las implicaciones del texto no son optimistas. A Víctor le ha tocado un papel pasivo en la cópula, y en su mirada se ve «esa simple voluntad, cuando no se tiene o no se es nada, de existir a cambio de otro» (130). Claramente, ha llegado al encuentro sin haber aún forjado su propia identidad. En el rechazo de la herencia hispánica, por parte del Heredia que se elige francés, y en la inmolación del niño mexicano, quien aporta su cuerpo más que su espíritu a la creación del nuevo hombre, sólo es posible leer una sentencia de muerte contra la incipiente identidad, mexicana o iberoamericana, a la que se le niega su tiempo de gestación, para que desaparezca reabsorbida en la matriz originaria de la cultura europea. La novela nos muestra, así, dos caminos falsos que convergen, desde extremos opuestos, para coincidir en una negación del México mestizo: el indianismo conservador del arqueólogo Heredia y el europeísmo autonegador representado por el alquimista del Clos des Renards. Esta nueva representación de ideologías, obviamente rechazadas por el autor, y sin posible vigencia para la actual sociedad mexicana, hace suponer que Fuentes les atribuye una supervivencia, a nivel de mitos o fantasmas colectivos, que es necesario seguir exorcizando.

Creemos que los aspectos antes señalados demuestran una relación estrecha entre la obra de Fuentes y los planteamientos teóricos del indigenismo, en la medida en que éste se define como un movimiento que parte del hecho biológico y cultural del mestizaje y se propone como tarea una integración social que es tanto económica y política como cultural ${ }^{32}$. E1

${ }^{32}$ En su Introducción a José María Arguedas, Formación de una cultura nacional indoamericana, 2. ${ }^{a}$ ed. (México: Siglo XXI, 1977), Angel Rama señala que el tercer período del indigenismo en el Perú, representado por la obra de Ciro Alegría y José María Arguedas, se caracteriza por «una dominante nota culturalista». Esta: caracterización es válida también para el indigenismo mexicano. 
análisis de México como una policultura es, previsiblemente, el aspecto de esta empresa a la que Fuentes aporta sus conocimientos, sus ideas y su imaginación. La revitalización de los mitos indígenas y la reescritura crítica del pasado en su obra son parte, pues, del proyecto de autorrecuperación y de integración nacional, que él concibe como única ideología posible de la mexicanidad. 
